\title{
Development of an Electrolytic Pilot Plant for the Production of Chlorine Gas "In Situ" in the Disinfecting Water Process
}

\author{
Ruben Guerra $^{1 *}$, Marlene Ballestas ${ }^{1}$, Alonso Barrera ${ }^{2}$, Vladimir Pinzón ${ }^{1}$, Henry Herrera ${ }^{2}$ \\ ${ }^{1}$ Department of engineering, ITSA University, Soledad, Colombia \\ ${ }^{2}$ Department of basic sciences, De la Costa University, Barranquilla, Colombia
}

Received: 19/08/2020

Accepted: 23/11/2020

Published: 20/03/2021

\begin{abstract}
Technology of gaseous chlorine in water treatment has shifted to the dosage of sodium hypochlorite or calcium hypochlorite because of their greater biocide power; require less contact time with the microorganisms in the pretreated water, and the $\mathrm{pH}$ of slightly affect water. The generation of chlorine gas in place is based on the principles of electrolytic dissociation and laws of electrolysis by Faraday. The equipment corresponds to an electrolytic cell of three (3) compartments, a central one (anode) where chlorine gas emerges , and two side (cathodes) where sodium hydroxide is produced in the central compartment must be refilled chloride solution sodium consumed due to the electrochemical reaction, the chlorine evolved being of gaseous nature ascends the column of sodium chloride and is captured by the vacuum venture system, who to put in direct contact with target that has been previously subjected to the processes of uptake , coagulation , sedimentation and filtration. Compartments anode-cathode - anode are physically separated by porous diaphragm, whose purpose is to permit selective flow of sodium and chloride ions, avoiding side reactions recombination, as additional product is the formation of sodium hydroxide in the cathode chambers, which should be removed from the cell through side pipes. Statistical models were used to optimize the performance and operation of the prototype.
\end{abstract}

Keywords: Saline electrolysis; chlorine gas; electrolytic reactor

\section{A Headings are the primary heading type}

One of the most common diseases among the population of Latin America are related to lack of water and contaminated water [1]; taking millions of lifes per year [2]. In most large cities in the country with more than 10000 inhabitants, chlorination has been made reasonably reliable using gaseous chlorine dosing technology supplied in cylinders, however, chlorination of potable water supply systems that serve smaller populations usually remains unreliable and intermittent [3]. To help solving this problem, many technological alternatives applicable to disinfection have been investigated [4 and 5]. These include various technologies suitable for ozonation [6], iodine [7], ultraviolet radiation [8], as well as the use of various methods for performing gas chlorination, chloramines, chlorine dioxide and methods for generating disinfectants in situ [9 and 10]. The latter method being the one that has proven to be the most promising of all the technologies used [10].

\section{Plant Development}

2.1 CAD design and construction electrolytic pilot plant for gas chlorine production

For the purpose of evaluating the performance of chlorinegenerating equipment in situ an electrolytic cell was designed and built (1), which is loaded with concentrated brine (6) to which electric current supplied by a DC power rectifier source is applied (3), the mixture of gases generated in the anode are extracted by the suction created by the Venturi system (2), the pump (5) circulates a working volume (4) of $200 \mathrm{lt}$ at a flow rate of 15,3 $\mathrm{Lt} / \mathrm{min}(9,18 \mathrm{mt} 3 / \mathrm{h})$, passing through the Venturi and the shunt (7). As seen in the Fig. 1 and Fig. 2.

\subsection{CAD design and construction of an electrolyte cell with a capacity of $15 \mathrm{~A}$}

The reactor design used in the tests consists of an electrolyte cell loaded with 20 liters of brine at concentrations of 45 and 68 gr NaCl/lt respectively, which produces oxidizing gases (chlorine and oxygen species) in the anode compartment, and sodium hydroxide and hydrogen in the cathode compartment, which is shown in the fig. 4 . These two compartments are separated by a semipermeable polysulfonated membrane usually made of Nafion @, General purpose material in the manufacture of car batteries, the prototype body was made of $5 \mathrm{~mm}$ thick transparent acrylic sheets resistant to the action of chlorine, ozone and $\mathrm{NaOH}$. The cathode of the unit is made of stainless steel and a matrix of 22 cylindrical graphite electrodes $10 \mathrm{~mm}$ in diameter by $300 \mathrm{~mm}$ of length.

*Corresponding author: Ruben Guerra, Department of engineering, ITSA University, Soledad, Colombia. 


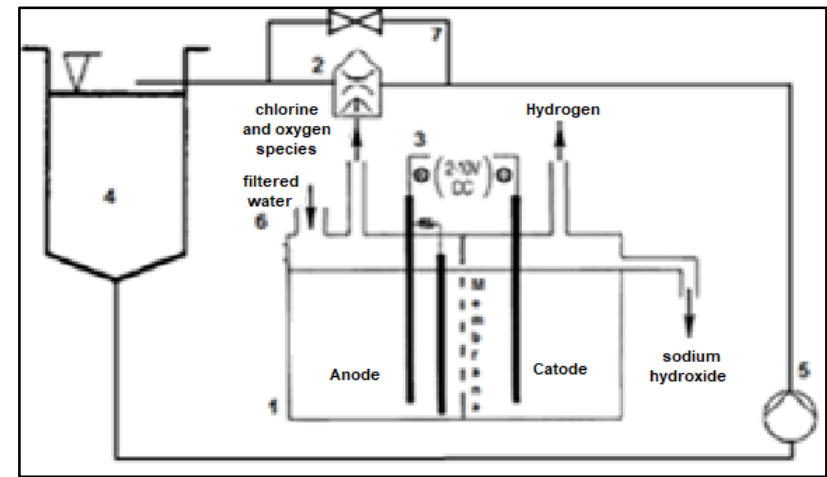

Figure 1: Schematic diagram of the test team

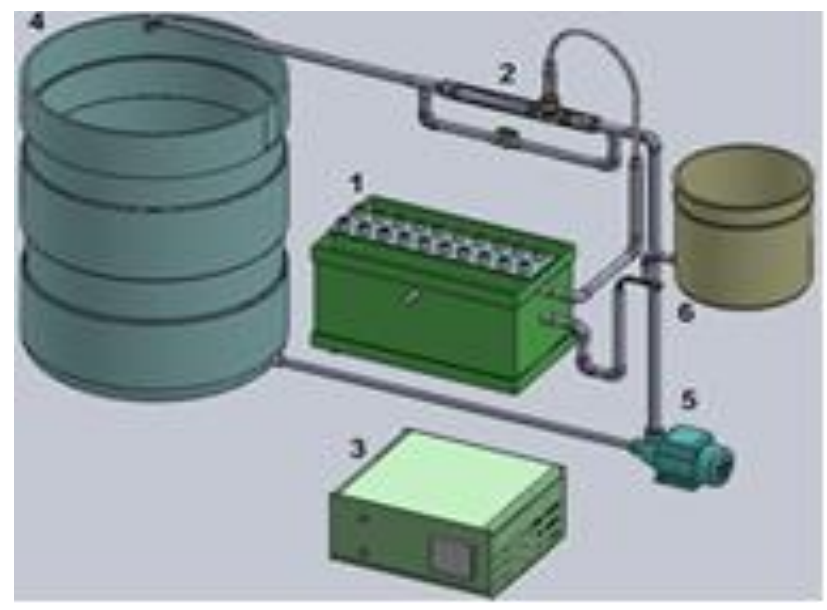

Figure 2: 3D design of the test team

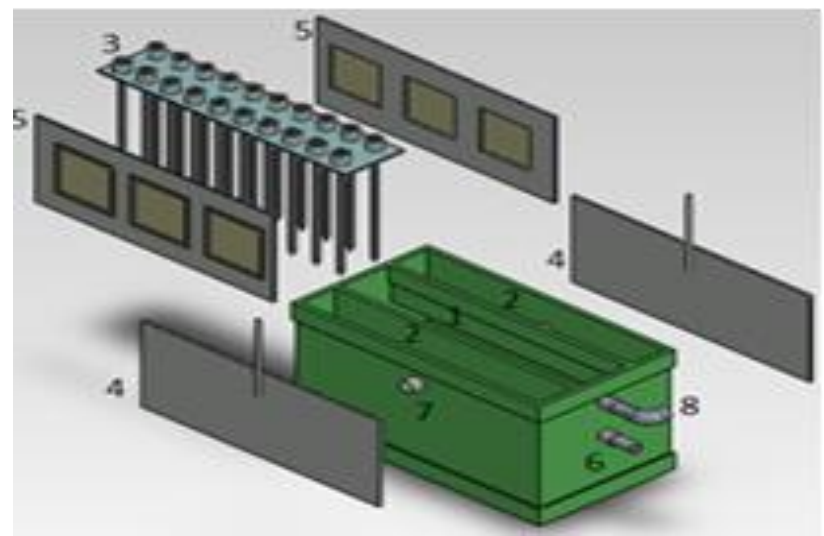

Figure 3: 3D design of the Electrolytic Cell generating oxidizing gas mixture with capacity of $15 \mathrm{~A}$

\subsection{CAD design and construction of a chlorine gas mixing system with water by Venturi principle}

The chlorination system applied in the project was developed with Venturi tube which is able to generate a suction of emptying in the anode chamber, enough to extract the production of oxidizing gases including chlorine gas, and injecting it directly into the pump-driven water stream, while serving as a mixing chamber between chlorine and water. A shut-off valve was arranged by pass with the Venturi, as shown in the fig. 5 , it allows you to adjust the intensity of the vacuum and create an alternate path to water, decreasing the pump load and increasing its flow rate.

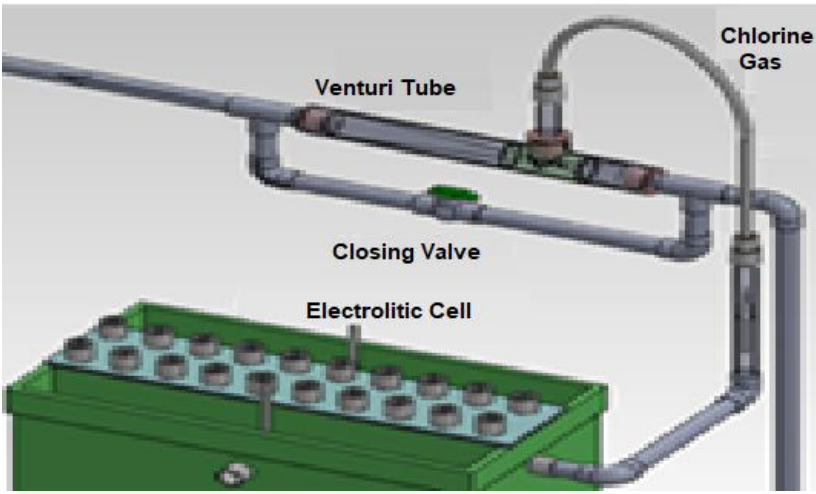

Figure 4: 3D design of chlorine gas mixing with Venturi

\subsection{Design and construction of a 25A DC electric power rectifier} source

For the supply of current to the electrolytic cell, a DC voltage source with a capacity of $25 \mathrm{~A}$ was implemented, which is shown in Fig. 6. The source construction is part of the maximum current and voltage values required by the cell.

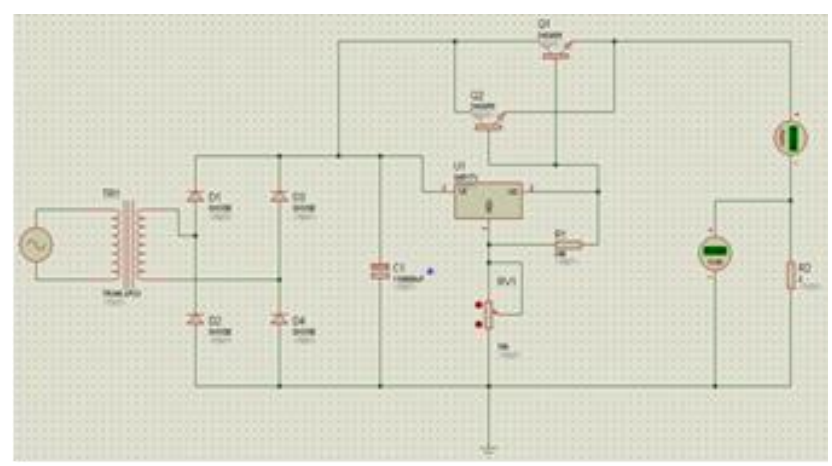

Figure 5: DC source electronic design

2.5 Construction of the sodium chloride solution dosing system

The level control in the reactor brine is based on the application of an operational amplifier working as a voltage comparator circuit, this is shown in the fig. 7 .

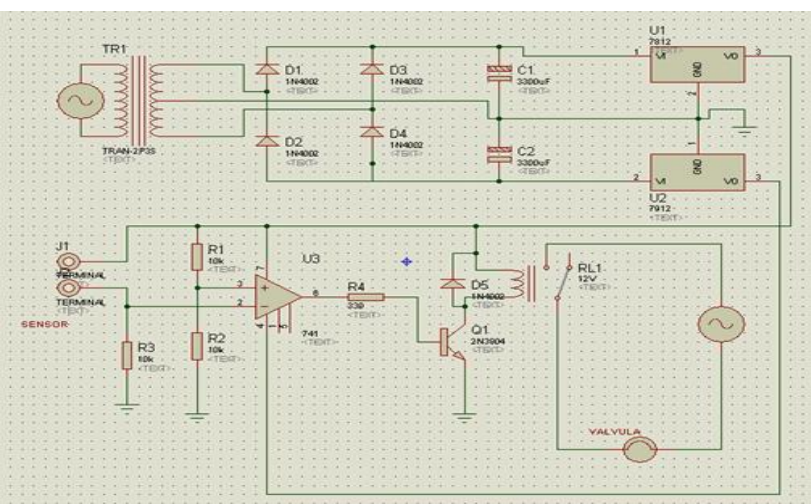

Figure 6: Electronic design of sodium chloride solution dosing system 


\subsection{Grafcet program for the automation of the chlorination plant}

The control of the equipment is clearly sequential, as shown in fig. 8, which objective is to turn outputs on and off (DC Source, Pump and Valve) coordinatedly, depending on the information of the entries (Start, Stop, Level R, Level T). While in its initial stage the program moves towards simultaneous activation of stages 2 and 3 that activate the DC Source and the pump after checking the minimum level in the tank and a call to start with the memory \% M5.

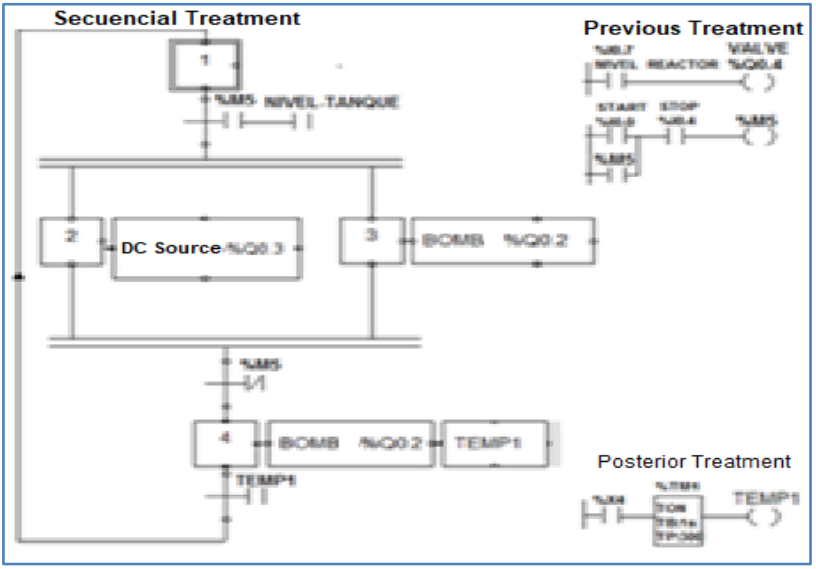

Figure 7: For the automation of the chlorination plant

\section{Checking and Verifying the Proposed System Using Statistical Models}

The previous study for the design of an electrolyte cell to produce chlorine gas in situ assumes that the most important factors affecting chlorine gas production and its $\mathrm{Cf}$ concentration (ppm) in the chlorine gas dissolution tank are:

- Current: It is the energy supplied by the DC voltage source (continuous current) and which can break down the molecular structure of the $\mathrm{NaCl}$ sodium chloride and thus produce the chlorine gas.

- Time: Duration of the process being tested and measured in minutes.

- Concentration: Number of grams of sodium chloride dissolved per liter of $\mathrm{NaCl}$ grams/liter solution.

- $P H$ : It is a measure of acidity or alkalinity of a dissolution The $\mathrm{PH}$ indicates the concentration of hydronium ions $\left(\mathrm{H}_{3} \mathrm{O}^{+}\right)$.

Table 1:

\begin{tabular}{|l|l|l|}
\hline Factors & Low Level & High Level \\
\hline Current & $10 \mathrm{~A}$ & $15 \mathrm{~A}$ \\
\hline Time & $20 \mathrm{~min}$ & $40 \mathrm{~min}$ \\
\hline Concentration & $45 \mathrm{gr} / \mathrm{lt}$ & $68 \mathrm{gr} / \mathrm{lt}$ \\
\hline $\mathrm{PH}:$ & $6.5\left(\mathrm{H}_{3} \mathrm{O}_{+}\right)$ & $7.5\left(\mathrm{H}_{3} \mathrm{O}_{+}\right)$ \\
\hline
\end{tabular}

\subsection{Selecting the response variable}

The response variable needed by the designer of an electrolyte cell for chlorine gas production is the final concentration of chlorine dissolved in parts per million of Chlorine ( $\left.\mathrm{PPM} \mathrm{Cl}{ }^{2}\right)$.

\subsection{Experimentation methodology}

This study case falls within the analysis of experiment 2 through 4 , in which there are 4 main factors, with 2 possible levels for each, the main interest of these tests being to determine which factors have the greatest significance in the response of the model studied, and to rule out the effects of non-significant factors, and is evidenced in Table II. Statistical model 2 through 4 includes 16 possible combinations of treatments for which the response may vary, each combination of treatment indicates the behavior of the output of the system or variable evaluated against random changes in the inputs. The tests were carried out in a Bach-like system. The production of free chlorine in the tank with $200 \mathrm{Lt}$ was estimated by applying the titration technique with chemical reagents, using the HTH product KIT. Measurements were made by extracting $8 \mathrm{~cm}^{3}$ of the treated water every 5 minutes and adding 5 drops of the ortho-tolidine reagent HTH ${ }^{\circledR}$ which causes the sample to take yellow hues, from the clearest to $0.5 \mathrm{PPM} \mathrm{Cl}^{2}$ to the most intense with $5 \mathrm{PPM} \mathrm{Cl}{ }^{2}$ determining concentration by visual comparison.

Table 2:

\begin{tabular}{|c|c|c|c|c|c|c|c|c|c|c|}
\hline & 登 & \begin{tabular}{|l}
8 \\
0 \\
8 \\
\end{tabular} & $\begin{array}{l}0 \\
0 \\
\end{array}$ & $\frac{8}{8}$ & & 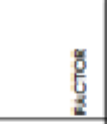 & 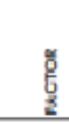 & 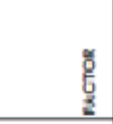 & $\begin{array}{l}\frac{0}{0} \\
\frac{2}{2}\end{array}$ & 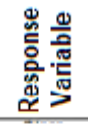 \\
\hline $\begin{array}{l}\frac{\pi}{2} \\
\\
\end{array}$ & A & B & C & D & $\begin{array}{l}\text { Treat. } \\
\text { Comb }\end{array}$ & $\begin{array}{c}\text { A: } \\
\text { CURRENT } \\
\text { (AMAO) }\end{array}$ & $\begin{array}{c}\text { B. } \\
\text { TIME } \\
\text { ( waw ) }\end{array}$ & 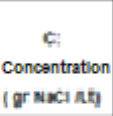 & 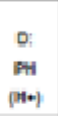 & $\begin{array}{c}\text { Free } \\
\text { Chlorine } \\
\text { PFw } \\
\text { con }\end{array}$ \\
\hline 1 & - & - & - & - & [1] & 10 & 20 & 45 & 8.5 & 2.5 \\
\hline 2 & * & $\overline{ }$ & $\cdot$ & . & $a$ & 15. & 20 & 45 & 6.5 & 16 \\
\hline 3 & $=$ & + &. & $=$ & b & 10 & 40 & 45 & 6,5 & 6 \\
\hline 4 & + & + & - & - & $a b$ & 15 & 40 & 45 & 6.5 & 20 \\
\hline 5 & 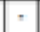 & $\pi$ & + & - & c & 10 & 20 & 68 & 6.5 & 12 \\
\hline 6 & + & - & 4 & - & $a c$ & 15 & 20 & 68 & 6,5 & 18 \\
\hline 7 &. & + & + & - & $\mathrm{be}$ & 10 & 40 & 88 & 8.5 & 20 \\
\hline 8 & $*$ & + & $*$ & - & abe & 15. & 49 & 88 & 8,5 & 25 \\
\hline 9 & $\cdot$ & $\overline{-}$ & $\cdot$ & $\cdot$ & d & 16 & 20 & 45 & 7,5 & $\bar{z}$ \\
\hline 10 & + &. & $\cdot$ & + & ad & 15 & 20 & 45 & 7,5 & 15 \\
\hline 111 & $\cdot$ & + & - & + & bd & 10 & 40 & 45 & 7,5 & 5,5 \\
\hline 12 & + & + & - & + & abd & 15 & 40 & 45 & 7.5 & 18 \\
\hline 13 & $\cdot$ & - & 4 & + & cod & 10 & 20 & 68 & 7,5 & 10 \\
\hline 14 & + & $\overline{-}$ & + & + & aed & 15 & 20 & 68 & 7,5 & 17 \\
\hline 15 & $\cdot$ & $*$ & $*$ & $\cdot$ & bed & 10 & 40 & 68 & 7,5 & 18 \\
\hline 16 & $1+$ & + & 4 & + & abcd & 15 & 40 & 68 & 7,5 & 24 \\
\hline
\end{tabular}

Multifactor variance analysis of data was developed with Statgraphics Centurion XV Version 16.1.11 Software. The Anova Multifactorial result for a Maximum Order of Effect of 2 (considering the effect of The Main Factors and Interactions only) shows the results in Table III. In this case, 3 effects and two interactions have a P-value less than 0.05 , indicating that they are significantly different from zero with a confidence level of $95.0 \%$. The R-Square statistic indicates that the model explains $98.503 \%$ of the variability in Cf (PPM). The adjusted R-square statistic, which is best suited for comparing models with different number of independent variables, is $98.4254 \%$. The Pareto diagram shows graphically in Fig. 9, the magnitude of the effects of factors on the final concentration $\mathrm{Cf}(\mathrm{ppm})$ in this case Factor A: Current; 
Factor B: Time; Factors C: Concentration; and factor A interactions with $\mathrm{C}$ and the interaction of factor $\mathrm{B}$ with $\mathrm{C}$. The ANOVA result is confirmed by the Normal Probability chart for the $\mathrm{Cf}(\mathrm{ppm})$ response where it is observed that Factor A: Current; Factor B: Time; Factor C: Concentration; and the interactions of $\mathrm{A}$ and $\mathrm{C}$; $\mathrm{B}$ and $\mathrm{C}$ are the most relevant in the system, because they move away from the normal probability line. The distribution of errors is normal indicating that Fig. 10 is a straight line.

Table 3:

\begin{tabular}{|l|l|l|l|l|l|}
\hline \multicolumn{1}{|c|}{ Source } & \multicolumn{1}{c|}{$\begin{array}{c}\text { Sum of } \\
\text { Squares }\end{array}$} & Df & \multicolumn{1}{c|}{$\begin{array}{c}\text { Sean } \\
\text { Square }\end{array}$} & $\begin{array}{c}\text { R- } \\
\text { Ratio }\end{array}$ & P-Value \\
\hline A. Current & 370,563 & 1 & 370,563 & 449,17 & 0,0000 \\
\hline B: Time & 121,0 & 1 & 121,0 & 146,67 & 0,0000 \\
\hline C: Concentration & 217,563 & 1 & 217,563 & 263,71 & 0,0000 \\
\hline AC & 52,5625 & 1 & 52,5625 & 63,71 & 0,0000 \\
\hline BC & 16,0 & 1 & 16,0 & 19,39 & 0,0013 \\
\hline Total error & 8,25 & 10 & 0,825 & & \\
\hline Total (corr.) & 785,938 & 15 & & & \\
\hline
\end{tabular}

Standard Error of Est. $=0,908295$ : Mean absolute error $=0,625$

Normal Probability Plot for Ct

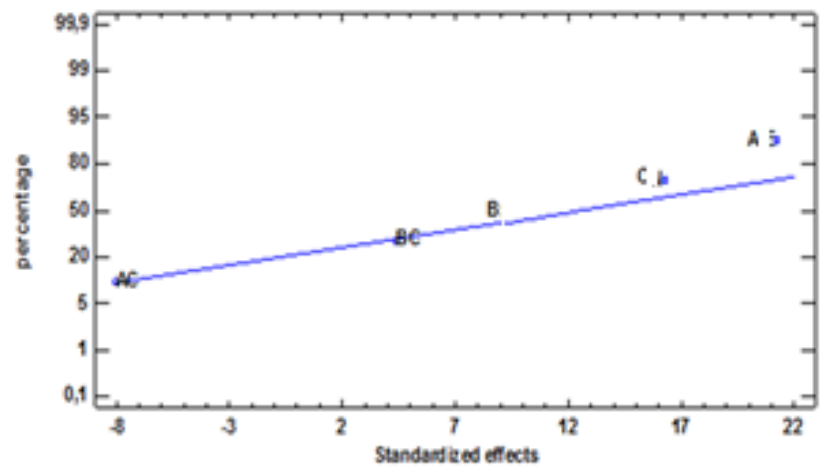

Figure 8: Normal Probability Chart

Table 4:

\begin{tabular}{|l|l|}
\hline Coefficient & Estimate \\
\hline constant & $-65,9022$ \\
\hline A: CURRENT & 5,48696 \\
\hline B: TIME & $-0,216304$ \\
\hline C: CONCENTRATION & 0,847826 \\
\hline AC & $-0,0630435$ \\
\hline BC & 0,00869565 \\
\hline
\end{tabular}

This analysis will only consider FactorS A: Current; Factor B: Time; Factor C: Concentration and interactions of A with $\mathrm{C}$ and $\mathrm{B}$ with $\mathrm{C}$, shown in Table IV. The No.1 regression equation obtained is: $\mathrm{Cf}(\mathrm{ppm})=-65,9022+5,48696 *$ Current $-0,216304 *$ Time + 0,847826* Concentration - 0,0630435* Current* Concentration $+0,00869565^{*}$ Time* Concentration. (See table V). It also yields Cf (PPM) values close to the model and experiment.

Table 5:

\begin{tabular}{|c|c|c|c|c|c|c|}
\hline 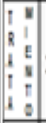 & $\begin{array}{c}\text { X1: Current } \\
\text { (AMPr) }\end{array}$ & $\begin{array}{c}\text { XetIME) } \\
\text { (MIN) }\end{array}$ & $\begin{array}{l}\text { X3: COYCEYTRATOY } \\
\text { N (WOLAROAD) }\end{array}$ & $X E-P H$ & $\begin{array}{c}\text { RESPONSE } \\
\text { VARIABLEC(F:PM ] } \\
\text { DPEERUEVTLI }\end{array}$ & \begin{tabular}{|l|} 
RESPONSE \\
VARIABLE (t:PFMI \\
REGRESSION \\
\end{tabular} \\
\hline 1 & 10 & 20 & 45 & 6,5 & 2,5 & 2,3 \\
\hline 2 & 10 & $n$ & 5 & 1,5: & 2 & 2,3 \\
\hline 3 & 10 & $x$ & 68 & 6,5 & 12 & 11.2. \\
\hline 4 & 10 & 20 & 68 & 17,5: & 10 & 1112 \\
\hline 5 & 10 & 40 & 45 & 6,5 & 6 & 5,8 \\
\hline 6. & 10 & 4 & 45 & 1,5.5 & 5,5 & 58 \\
\hline 7 & 10 & 4 & 68 & 6,5 & 20 & 8,7 \\
\hline 3 & 10 & $M$ & 68 & 17,5. & 18 & 18,7 \\
\hline 4) & 15 & $x$ & 5 & 6,5 & 16 & 15,5 \\
\hline 1. & 15 & $x$ & 5 & 1,5:5. & 15 & 15,5 \\
\hline 11. & 15 & 20 & 68 & 6,5 & 18 & 11,3 \\
\hline 12] & 15 & $n$ & 68 & 1,5.5. & 1) & 17,3 \\
\hline 13 & 15 & 40 & 45 & 6,5 & 20 & 1,0 \\
\hline 14 & 15 & 40 & 45 & 1,5 & 18 & 19,0 \\
\hline 15 & 15 & $M$ & 68 & 6,5 & $x$ & 24,8 \\
\hline 16] & 15 & 40 & 68 & 1,5:5 & 24 & 248 \\
\hline
\end{tabular}

Figure 9 reveals the good correlation between the results of free chlorine measurements against regression values.

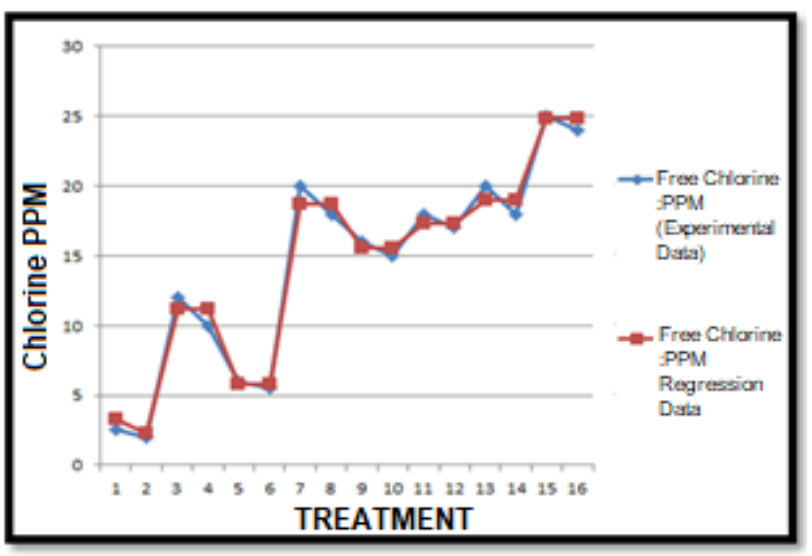

Figure 9: Experimental free chlorine Vs estimated (regression No1)

The number of levels was expanded to three (3) for each significant factor in order to obtain a more reliable regression curve tailored to the model, with a factorial design 33 of 27 treatments, as recorded in TABLE VI. As a result of regression analysis No2, applied to Table 5, a curve is shown in Tables 7 and 8 , a curve that only contemplates the most important factors (Current-Time and Concentration).

Regression Model $\mathrm{N}^{\circ} 2$

Cf $(\mathrm{I}, \mathrm{T}, \mathrm{C})=-0,56052632+0,27397661 *$ Current $+0,13055556^{*}$ Time $+0,02202643 *$ Concentration.

Noting that the regression coefficient associated with the Concentration factor is very low (0.02202643), a new regression was found that only considers the most significant factors 
(Current and Time) resulting in a regression model $\mathrm{N}^{\circ} 3$ simpler of the process, which is evidenced in the tables 9 y 10 , fig. 12 .

Table 6:

\begin{tabular}{|c|c|c|c|c|c|c|}
\hline \multirow[b]{3}{*}{ Treabmente } & \multirow{2}{*}{\multicolumn{3}{|c|}{ FACTOK }} & \multicolumn{3}{|c|}{ VARLAEUE DE RESPUESTA } \\
\hline & & & & \multirow{2}{*}{$\begin{array}{c}\begin{array}{c}\text { Experimental } \\
\text { Masaure }\end{array} \\
\text { Ci (DPM) } \\
\text { Residual } \\
\text { Chlorine } \\
\end{array}$} & \multicolumn{2}{|c|}{$\begin{array}{l}\text { Varlable } \\
\text { Respense }\end{array}$} \\
\hline & $\begin{array}{c}\text { ' } \\
\text { CURRENT } \\
\text { (A) }\end{array}$ & $\begin{array}{c}\mathrm{T} \\
\text { TIME } \\
\text { (MiN) } \\
\end{array}$ & $\begin{array}{c}c \\
\begin{array}{c}c \\
\text { Concentration } \\
\text { (er Nacilistres) }\end{array} \\
\end{array}$ & & $\begin{array}{c}\text { Cf(PPM) } \\
\text { Regression } \\
(t, 1 ; C)\end{array}$ & $\begin{array}{c}\text { Cf(PDM) } \\
\text { Regression } \\
(\mathrm{T})\end{array}$ \\
\hline 1 & 10 & 20 & 45.4 & 2 & 1.79 & 2.04 \\
\hline 2 & 10 & 20 & 56.75 & 22 & 2.04 & 2.04 \\
\hline 3 & 10 & 20 & 68.1 & 25 & 2.29 & 2.04 \\
\hline 4 & 10 & 30 & 45.4 & 3 & 3.10 & 3.35 \\
\hline 5 & 10 & 30 & 56,75 & 32 & 3.35 & 3.35 \\
\hline 6 & 10 & 30 & 68.1 & 3.5 & 3.60 & 3.35 \\
\hline 7 & 10 & 40 & 45.4 & 4.5 & 4.40 & 4.65 \\
\hline 8 & 10 & 40 & 56.75 & 4.6 & 4.65 & 4.65 \\
\hline 9 & 10 & 40 & 68.1 & 5 & 4.90 & 4.65 \\
\hline 10 & 12 & 20 & 45.4 & 24 & 2.34 & 2.59 \\
\hline 11 & 12 & 20 & 56,75 & 25 & 2.59 & 2.59 \\
\hline 12 & 12 & 20 & 68.1 & 3 & 2.84 & 2.59 \\
\hline 13 & 12 & 30 & 45.4 & 3.5 & 3.64 & 3.89 \\
\hline 14 & 12 & 30 & 56,75 & 4 & 3.89 & 3.89 \\
\hline 15 & 12 & 30 & 68.1 & 4 & 4.14 & 3.89 \\
\hline 16 & 12 & 40 & 45.4 & 48 & 4.95 & 5.20 \\
\hline 17 & 12 & 40 & 56,75 & 5 & 5.20 & 5.20 \\
\hline 18 & 12 & 40 & 68.1 & 5.2 & 5.45 & 5.20 \\
\hline 19 & 15 & 20 & 45.4 & 3 & 3.16 & 3.41 \\
\hline 20 & 15 & 20 & 56.75 & 32 & 3.41 & 3.41 \\
\hline 21 & 15 & 20 & 68.1 & 3.5 & 3.65 & 3.41 \\
\hline 22 & 15 & 30 & 45.4 & 4.5 & 4.47 & 4.72 \\
\hline 23 & 15 & 30 & 56.75 & 48 & 4.72 & 4.72 \\
\hline 24 & 15 & 30 & 68.1 & 5 & 4.97 & 4.72 \\
\hline 25 & 15 & 40 & 45.4 & 6 & 5.77 & 6.02 \\
\hline 26 & 15 & 40 & 56.75 & 6.2 & 6.02 & 6.02 \\
\hline 27 & 15 & 40 & 68.1 & 6.5 & 6.27 & 6.02 \\
\hline
\end{tabular}

Table 7: Regression statistics No2

Regression statistics No2

\begin{tabular}{|l|l|}
\hline Multiple correlation coefficient & 0.992270038 \\
\hline Determination coefficient $\mathrm{R}^{2}$ & 0.984599828 \\
\hline Adjusted R & 0.9825111 \\
\hline Typical error & 0.165675926 \\
\hline Observations & 27 \\
\hline
\end{tabular}

Table 8: Regression statistics No2

\begin{tabular}{|l|l|l|}
\hline Regression Model No. 2 & Coefficients & P Value Probability \\
\hline & -4.5605263 & $1.62817 \mathrm{E}-13$ \\
\hline Interception & 0.27397661 & $7.17884 \mathrm{E}-15$ \\
\hline Variable X 1 (Current) & 0.13055556 & $5.27966 \mathrm{E}-21$ \\
\hline Variable X 2 (Time) & 0.02202643 & $1.56206 \mathrm{E}-06$ \\
\hline Variable X 3 (Concentration) & & \\
\hline
\end{tabular}

Regression Model No3

$\mathrm{Cf}=-3,31052632+0,27397661 *$ Current $+0,13055556 *$ Time

Table 9: Regression statistics No3

Regression statistics No3

\begin{tabular}{|l|l|}
\hline Multiple correlation coefficient & 0.978343926 \\
\hline Determination coefficient $\mathrm{R}^{2}$ & 0.957156837 \\
\hline Adjusted $\mathrm{R}^{2}$ & 0.953586574 \\
\hline Typical error & 0.27 .517697 \\
\hline Observations & 27 \\
\hline
\end{tabular}

Table 10:

\begin{tabular}{|l|l|l|}
\hline Regression Model No. 3 & Coefficients & P Value Probability \\
\hline & -3.310526316 & $1.62817 \mathrm{E}-13$ \\
\hline Interception & 0.273976608 & $1.04431 \mathrm{E}-10$ \\
\hline Variable X 1 (Current) & 0.13055556 & $5.27966 \mathrm{E}-21$ \\
\hline Variable X 2 (Time) & 0.130555556 & $1.56206 \mathrm{E}-06$ \\
\hline Variable X 3 (Concentration) & \\
\hline
\end{tabular}

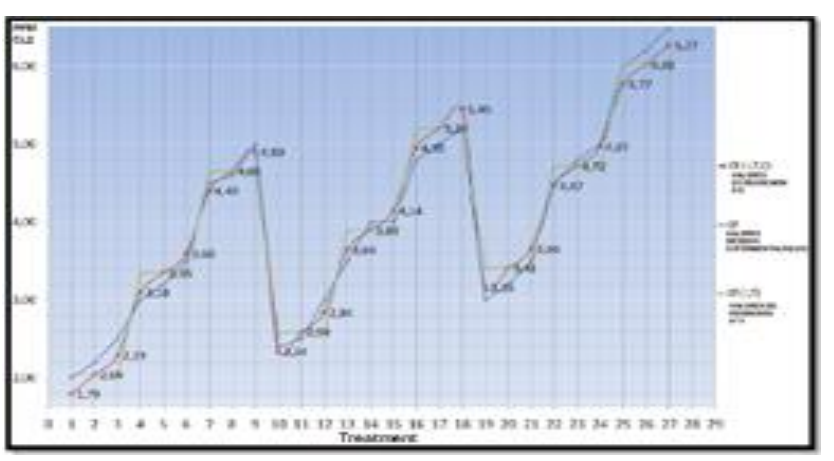

Figure 10: Regression graphs (Experimental, $\mathrm{N}^{\circ} 2$ y Nº3)

\subsection{Residual analysis}

There is no characteristic pattern, this indicates that the residues are independent or randomly distributed. Fig. 13 does not see any pattern or funnel shape, so the data can be considered to satisfy the linearity criterion. The debris fits quite well to a straight. The points (errors) fall close to the straight line, distributed both above and below it, i.e. there is no characteristic pattern, indicating that the residues are independent and randomly distributed, in conclusion, there is normality in the errors.

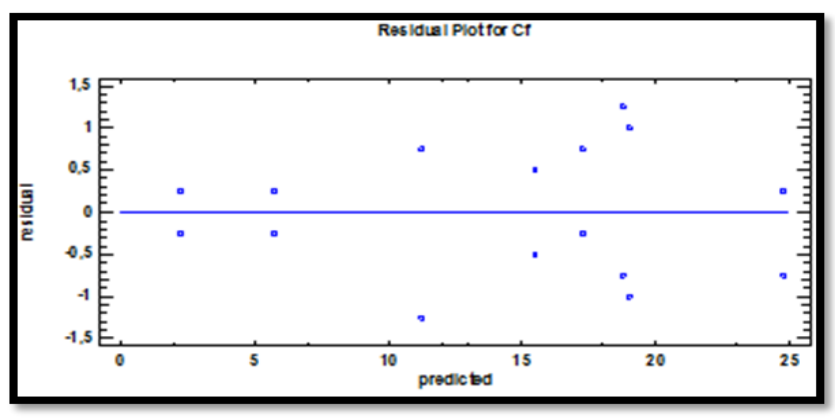

Figure 11: Residual analysis

\subsection{Response surface}

Three-dimensional response surface where cf (PPM) production of gaseous chlorine is observed based on current and time. In this case there are two influence factors (k-2), the response surface is displayed in a three-dimensional space in which the third dimension represents the expected production of chlorine gas $\mathrm{Cf}(\mathrm{ppm})$ on the two-dimensional plane defined by the combinations of the current and time factor levels, shown in Figure 12. 


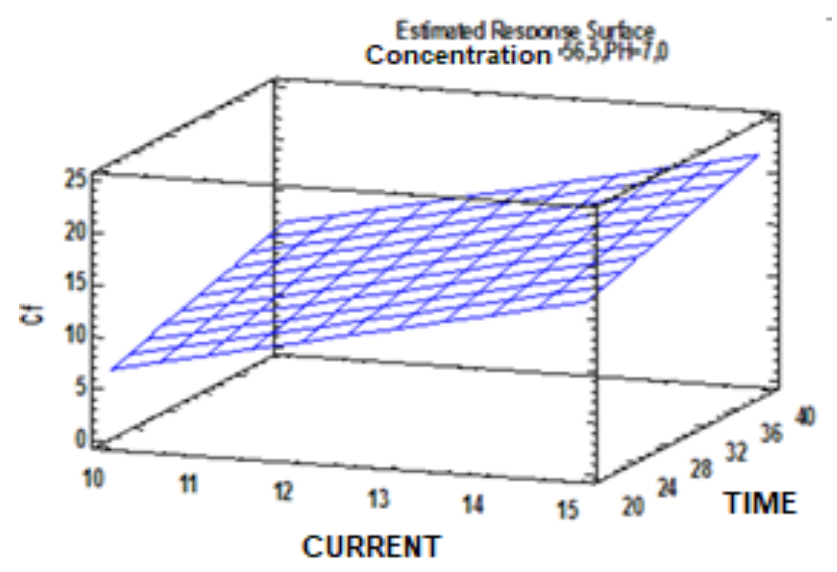

Figure. 12: Response surface

\subsection{Equipment performance in closed-circuit recirculation}

The team's behaviour was assessed by measuring the increase in $\mathrm{Cl} 2$ concentration by a volume of 200lt that was recirculated at a flow rate of $15.3 \mathrm{Lt} / \mathrm{min}$, incrementally capturing the gases generated through the Venturi. And it is evidenced in Table 11 and fig. 15. For this test, the cell was loaded with $20 \mathrm{Lt}$ of brine at a concentration of $45 \mathrm{gr}$ of $\mathrm{NaCl} / \mathrm{Lt}$ and a current of $8 \mathrm{~A}$ in the source. It should be noted that these current and concentration levels can be considered as the minimum adjustment levels of the equipment, being able to work at concentrations of $68 \mathrm{gr}$ of $\mathrm{NaCl} / \mathrm{Lt}$ and $15 \mathrm{~A}$.

Table 11:

\begin{tabular}{|c|c|}
\hline TIME (Min) & $\begin{array}{c}\text { Free Chlorine: PPM Current I: 8A } \\
\text { Concentration: 45grNacl/Lt }\end{array}$ \\
\hline 0 & 0.0 \\
\hline 5 & 1.0 \\
\hline 10 & 1.5 \\
\hline 15 & 2.0 \\
\hline 20 & 3.0 \\
\hline 25 & 4.0 \\
\hline 30 & 5.0 \\
\hline 35 & 6.0 \\
\hline 40 & 8.0 \\
\hline 45 & 9.0 \\
\hline 50 & 9.5 \\
\hline 55 & 10.0 \\
\hline 60 & 10 \\
\hline
\end{tabular}

This test reveals that even at minimum adjustment levels the equipment could leave a 10 PPM footprint on 200lt of water which would amount to saying it would take $2 \mathrm{~m} 3$ of water to 1 PPM in an hour.

\subsection{Open circuit - Performance without recirculation}

For this test, the cell was loaded with $20 \mathrm{Lt}$ of brine at a concentration of $45 \mathrm{gr}$ of $\mathrm{NaCl} / \mathrm{Lt}$ and a current of $10 \mathrm{~A}$ in the source. The total time of the experiment was $360 \mathrm{~min}$, during this time it is observed the increase in the concentration of the output flow from a value of $1 \mathrm{ppm}$ to the five minutes of the test to a value of $14 \mathrm{ppm}$ at $360 \mathrm{~min}$ of the test, keeping this value

containing after this time, this data is shown in TABLE 12 and Fig. 16.

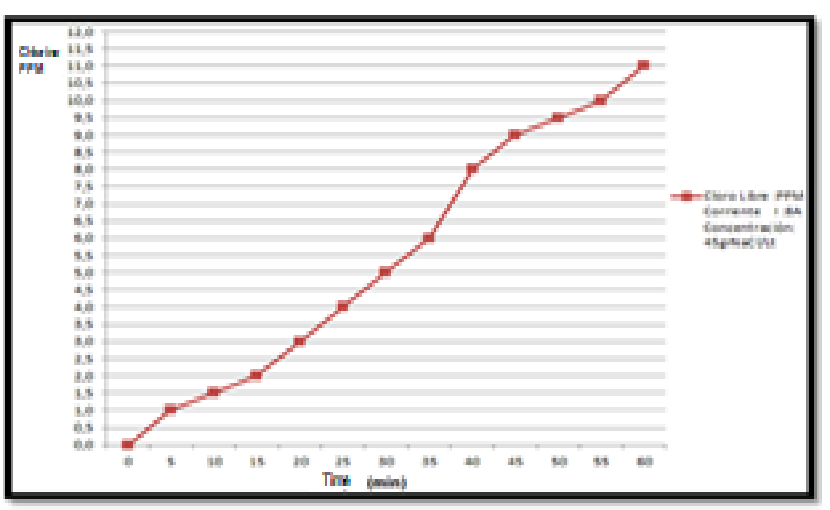

Figure. 13: Closed circuit - Recirculation performance

Table 12:

\begin{tabular}{|c|c|c|c|}
\hline \multicolumn{4}{|c|}{ Chlorine accumulation in a 200Lt water Volume } \\
\hline $\begin{array}{c}\text { Time } \\
\text { Min) }\end{array}$ & $\begin{array}{c}\text { Free Chlorine :PPM } \\
\text { Current I:10A } \\
\text { Concentration: } \\
\text { 45grNaCl/Lt }\end{array}$ & $\begin{array}{c}\text { Time } \\
\text { (Min) }\end{array}$ & $\begin{array}{c}\text { Free Chlorine :PPM } \\
\text { Current I:10A } \\
\text { Concentration: } \\
\text { 45grNaCl/Lt }\end{array}$ \\
\hline 0 & 0.0 & 195 & 8.5 \\
\hline 15 & 1.0 & 210 & 9.0 \\
\hline 30 & 1.5 & 225 & 9.5 \\
\hline 45 & 2.0 & 240 & 10.0 \\
\hline 60 & 3.0 & 255 & 11.0 \\
\hline 75 & 3.5 & 270 & 11.5 \\
\hline 90 & 4.5 & 285 & 12.0 \\
\hline 105 & 5.0 & 300 & 12.5 \\
\hline 120 & 6.0 & 315 & 13.0 \\
\hline 135 & 6.5 & 330 & 13.5 \\
\hline 150 & 7.0 & 345 & 14.0 \\
\hline 165 & 7.0 & 360 & \\
\hline 180 & 8 & & \\
\hline
\end{tabular}

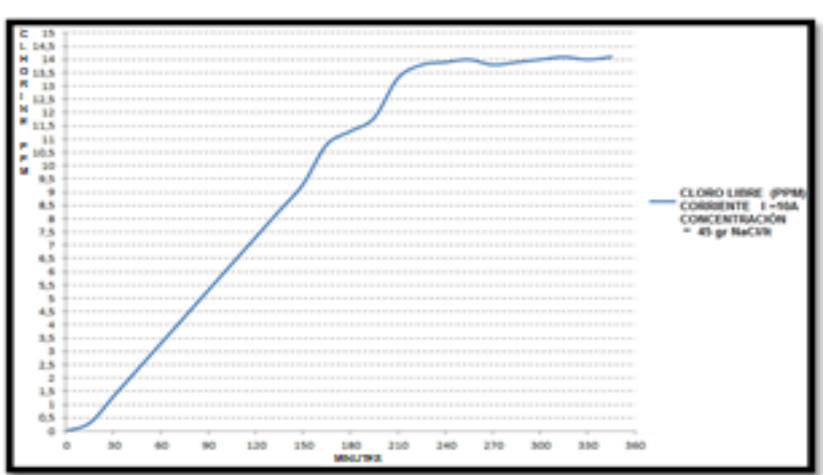

Figure. 14: Open circuit - Performance without recirculation

With these concentration and flow values the equipment can carry a flow rate of $12.8 \mathrm{~m} 3$ to $1 \mathrm{ppm}$ of chlorine in one hour. The measurement of equivalent residual chlorine was carried out as follows:

- Water samples were taken every 15 minutes in a specimen, added to the $\mathrm{Cl}_{2}$ meter by comparison.

- Adding 5 drops of Orthotolidine Hydrochloride.

- The color of the sample was compared to the meter standards 
by colorimetric comparison of the sample. $0,5-5$ PPM.

When the concentration exceeded 5 PPM dilutions were made in which $10 \mathrm{ml}$ of the sample was taken and taken to $20 \mathrm{ml}, 30 \mathrm{ml}$, $40 \mathrm{ml}, 50 \mathrm{ml}, 60 \mathrm{ml}$, with distilled water and this solution samples were taken for comparison. Dilutions were taken into account to calculate the total amount of residual chlorine in treated water.

\section{Conclusions}

- The prototype meets expected expectations with an efficiency greater than $85 \%$.

- The operation and maintenance of the equipment is very simple. The steps for this procedure would be: Cell washing after each operation, brine supply for a new chlorine gas production, recirculation pump ignition and level control system, automated controller ignition.

- The equipment can work with batteries powered by solar cells. This would be applied in regions where there is no power supply of the electric fluid.

- The equipment can treat flow rates greater than $300 \mathrm{~m} 3 /$ day with a concentration of $1 \mathrm{ppm}$; this is possible since the electrolyte cell produces other oxidizing gases such as ozone, this increases the ability to water to almost double what is calculated.

- If we assume a consumption of 100 liters per person per day; 3000 people can be served, at a cost of $\$ 27.40$ person/month.

- The equipment avoids the need to handle and import cylinders with chlorine gas or liquid sodium hypochlorite drums.

\section{Aknowledgment}

The authors thanks the journal of environmental treatment techniques for ginvig this space to develop the sciences.

\section{Ethical issue}

Authors are aware of, and comply with, best practice in publication ethics specifically about authorship (avoidance of guest authorship), dual submission, manipulation of figures, competing interests and compliance with policies on research ethics. Authors adhere to publication requirements that submitted work is original and has not been published elsewhere in any language.

\section{Competing interests}

The authors declare that there is no conflict of interest that would prejudice the impartiality of this scientific work of Development of an electrolytic pilot plant to produce chlorine gas "in situ" in the disinfecting water process.

\section{Authors' contribution}

All authors of this study have a complete contribution for data collection, data analyses, manuscript writing and transalate process.

\section{References}

1 Lara H, García EM. Prevalencia de enfermedades asociadas al uso de agua contaminada en el Valle del Mezquital. Entreciencias: diálogos en la sociedad del conocimiento. 2019 oct 18.

2 Rodríguez JP, García CA, García, J. C. (2016). Enfermedades transmitidas por el agua y saneamiento básico en Colombia. Revista de salud pública. 2016 july 22.
3 Carrasco IR, Morales HS. Importancia de la cloración del agua: sitios de abastecimiento con presencia de bacterias patógenas. Enfermedades Infecciosas y Microbiología. 2019 may 15.

4 González L, Saavedra N, Saavedra A. Tecnologías e innovaciones para la purificación del agua. Teoría y praxis investigativa. 2018 july 12.

5 Bolisetty S, Peydayesh M, Mezzenga R. Sustainable technologies for water purification from heavy metals: review and analysis. Chemical Society Reviews. 2019 jan 03.

6 Sánchez GM. (2019). Agua ozonizada, antecedentes, usos en medicina y bases preclínicas. Revista Española de Ozonoterapia. 2019 jan 15.

7 Song K, Mohseni M, Taghipour F. Application of ultraviolet lightemitting diodes (UV-LEDs) for water disinfection: A review. Water research. 2016 march 03.

8 Wang L, Wang Z, Zhang L, Hu C. Enhanced photoactivity of Bi2WO6 by iodide insertion into the interlayer for water purification under visible light. Chemical Engineering Journal. 2018 aug 28.

9 Gea-Izquierdo E. Métodos de desinfección del agua y su implicación en la legionelosis. Tecnología y ciencias del agua. 2018 march 02.

10 Givirovskiy G, Ruuskanen V, Ojala L, Kokkonen P, Ahola J. In situ water electrolyzer stack for an electrobioreactor. Energies. 2019 may 18. 